\title{
USING ACTIVITIES AS A WAY OF PROCEDURALIZATION OF LEARNERS' LANGUAGE KNOWLEDGE
}

The new education law [20, p. 5] emphasizes the importance of studying foreign languages in which learners should gain communicative competence and reach $B 2$ level of the Common European Framework [2007] when they finish their secondary education. In order to achieve this objective, learners need to gain procedural knowledge of the target language. This objective is achievable if teachers activate learners and let them construct their own meanings of language in activities focused on gaining not only declarative knowledge, but also language habits and secondary language skills. Activities enable learners to work independently; teach them to think productively; and thus contribute to the development of their cognitive skills and autonomy. The multi-directional communication helps learners gain communicative competence and contributes to learners' socialization.

Key words: proceduralization of knowledge, declarative knowledge, accuracy-focused activities, fluency-focused activities, language habits, secondary language skills, activating methods

\section{Introduction}

Since September 2008, the education reform introduced immediately after the change in 1989 has been taking place in Slovakia. The Education Law No. 245/2008 Coll., passed in May 2008, emphasizes those changes in the content of education that are aimed at the development of general and cognitive competences of learners [1, p. 61], as well as communicative competences gained not only in the mother tongue but also in at least two foreign languages [20, p. 5].

Based on this context, we analyze the objectives of foreign language learning and discuss the importance of explicit and implicit language for the achievement of these objectives. In addition to that we discuss differences between techniques and activities and offer a definition of those activities that engage learners with the learning process and help them gain not only explicit but also implicit language knowledge and thus achieve the objectives of language learning.

\section{Engagement with the learning process}

The communicative approach to language learning is based on the theory of constructivism and as such it lays particular stress on the importance of experience, contextualization and authenticity. "The learning of skills and sub-skills, automatization of skills, meaningful learning (carrying out meaningful tasks) is preferable to rote learning. Emphasis is put on procedural knowledge and skills are automatized through controlled processing. Knowledge of a language, which is based on knowledge of actual usage, is dynamic. It changes in accordance with a person's linguistic experience $[15$, p. 53]."

This means that learners need to take an active part in the learning process, to construct meanings in the foreign language, produce restricted and/or authentic output and use language in a variety of communicative situations. In order to achieve the communicative competence as it is defined in the Common European Framework $[5$, p. 13] it is necessary to use activities that make these objectives achievable, activate learners and make multi-dimensional interaction possible.

[17, p. 41] defines activity as "the basic building block of a lesson... as something that learners do that involves them using or working with language to achieve some specific outcome." This understanding of an activity makes it clear that whatever is done by the teacher in the classroom (e.g. grammar explanation) is not considered an activity and should be referred to as technique [2, p. 16]. The concept of an activity also differs from that of a task which [19, p. 23] understands as "a goal-oriented communicative activity with a specific outcome, where the emphasis is on exchanging meanings not producing specific language forms."

In our conditions, most pupils and students learn a foreign language in school conditions, and usually are not exposed to them or do not use them in real communicative situations outside the class. Therefore, we believe that it is essential for them to have suf-

\footnotetext{
* Danica Gondova

Department of English Language and Literature, Faculty of Science, University of Zilina, Slovakia, E-mail: danica.gondova@fpv.uniza.sk
} 
ficient accuracy-focused and fluency-focused practice at schoo which they can get through engagement with activities. Similarly to [17, p. 41), we also define an activity as something that learners do by themselves and (if possible) independently from the teacher. It involves them in working with or using the target language, in other words, in producing a purely 'for-the-purposes-oflearning' (grammatical or vocabulary exercises) or 'real-world' outcomes (meaningful, communicative activities).

\section{Declarative and Procedural Language Knowledge}

Language learning is a very complex process, and teaching and learning foreign languages has its specifics since the ultimate objective for learners is to gain the communicative competence and master language skills not language knowledge. At the end of the course learners do not need to know about language (explicit or declarative knowledge), but they need to be able to use it and they need to have language habits and secondary language skills (implicit or procedural knowledge) [3, p. 43]. In other words, learners do not need to be able to talk about grammar but they need to be able to use it for communicative purposes. Therefore, effective language learning methods are those that lead to achieving all communicative sub-competences and within them - the language skills.

[4, p. 74] differentiates three types of objectives in language teaching: language, cognitive and affective objectives. Yet, he considers the language objective, which is gaining the communicative competence, to be the most important. He also emphasizes the significance of cognitive objectives, but these are linked with the extra-linguistic reality. This is because learners use the target language as a means to solve real-life problems. As such these are not the primary goals of language learning. The position of affective objectives in foreign language learning has a position similar to that of cognitive objectives.

[11, pp. 28-30] understands foreign language learning as a kind of movement from explicit to implicit knowledge or from declarative knowledge to its proceduralization. In her understanding conscious and declarative (explicit) knowledge (about language) has its meaning particularly if learners study the foreign language in school conditions because they have few opportunities to acquire language outside the school. In this case the explicit knowledge may accelerate the process of learning; however, it must be followed by the process of proceduralization. During the proceduralization process the explicit knowledge changes into procedural (implicit) knowledge, thanks to which learners gain secondary language skills [4]. "Explicit knowledge is declarative, while implicit knowledge is subconscious and procedural even though not necessarily automated" [11, p. 35].

From the point of grammar, which is often considered to be the core of language learning by both learners and teachers, explicit knowledge of rules is not sufficient; one also has to understand them either intuitively or consciously. Learners do not need to verbalize rules, but have to be able to use language structures cor- rectly. It is necessary to remember though, that in order to gain explicit knowledge learners need to be cognitively mature. This approach can be used with adults (including lower and upper secondary school students) whose cognitive thinking is already developed.

To conclude, even though teaching explicit knowledge is necessary, it is not sufficient and has to be followed by proceduralization. Practising language on sentence level (decontextualized exercises) is not enough. Learners need to be put in situations in which they are made to use the target structures in communicative activities. Teachers in Slovakia proclaim that they use communicative activities, but research results show [11, pp. 53-54] that in the teaching process they emphasize the importance of declarative knowledge which they tend to overestimate. On the other hand, learners are frustrated because they realize that their procedural knowledge has not been developed sufficiently. Similarly, in her research [14, p. 58] found out that learners achieve better results in discreteitem test-tasks than they do in language-in-use tasks even though their teachers declare that in the teaching process they use communicative activities.

\section{Accuracy Focused and Fluency-Focused Activities}

In order to achieve the objectives of foreign language teaching, teachers need to use a variety of activities which enable learners to gain language habits and/or secondary language skills, and which should prevail in language lessons. From this it follows that teachers should reduce the time spent on explaining grammatical rules and follow-up drills and support learners in using language in real-life situations $[15$, p. 60].

In the 1960s [12] divided techniques used in foreign language learning into manipulative and communicative. Manipulative are those in which the learner "receives the words or structures from teacher, tape or book", on the other hand, communicative are "those that allow the student himself to find the words or structures he uses” [12, p. 3].

Nowadays the activities are differentiated in the same way. The most important aspect is the degree of language control by the teacher. On the one side of the continuum there are accuracyoriented activities, in some literature also referred to as controlled or systems-oriented activities. These are considered to be traditional and controlled techniques are commonly used in the grammartranslation method and/or audio-lingual method [10]. Through semi-controlled and semi-free activities learners proceed gradually to the other side of the continuum to the activities that are fluencyfocused (also referred to as free or skills-oriented). The freer is the language whose production is made possible by an activity, the more effective is the proceduralization of language knowledge and the development of secondary language skills.

The transition from controlled to free activities is usually phased and fairly slow. The order of the activities is important and the teacher needs to choose them carefully so that learners can 
proceed from easier to more demanding tasks. Accuracy-oriented activities are easier for learners because the language they have to use is given to them. They are done in pairs or in small groups and thus they activate learners, are learner-centred, and help learners construct their own meanings of language structures. From the point of view of language they are manipulative because learners' responses can be predicted. On the other side of the continuum there are activities whose main objective is communication; the language learners use to talk about opinions, feelings, or attitudes is open and not predictable. These are considered as communicative because they enable the independent production of language used for expressing one's own ideas in a multi-directional communication.

Communicative activities help learners achieve the objective of language learning which, as mentioned above, is gaining communicative competence. That means being able to interact in various socio-linguistic situations and applying both explicit and implicit knowledge in one's own creative production of language in order to express one's own thoughts, feelings, experiences and attitudes. Among the characteristic features of authentic communicative situations is their complexity that requires the so called total skills, not isolated skills [15, p. 67]. The integration of language skills (total skills) in real-life communicative situations and in real time means that learners have to be able to decode the language they receive, i.e. analyze and comprehend the utterance they are listening to or reading and formulate the answer readily which, of course, requires implicit language knowledge.

\subsection{Classification of Activities in Foreign Language Learning/Teaching}

In order to achieve the above mentioned goals, it is necessary to activate learners at all levels of language proficiency and at all stages of language learning. For these reasons we differentiate:

a) activities which enable learners to gain explicit knowledge;

b) activities which enable learners to gain language habits;

c) activities which enable learners to gain secondary skills and communicative competence.

From this it follows that activities:

a) enable learners the proceduralization of language knowledge, i.e. the development of language habits and secondary skills; while using them learners are allowed to produce partly restricted or authentic language; express their own ideas, and opinions, and to control the meaning of their utterances using the implicit language knowledge;

b) enable learners to gain explicit language knowledge; even though they do not lead directly to gaining language habits and skills, they make it possible for learners to comprehend rules, forms and meanings of grammatical structures, vocabulary, pronunciation and spelling.

Generally, methods that enable multi-directional communication and independent work of learners are often referred to as activating methods $[6, \mathrm{p} .72]$. They require learners to solve various problems; develop learners' higher-order thinking skills; and teach them responsibility for their own learning. Some of them can also be used in foreign language teaching. Our classification of these activities is based on the classification of activating methods worked out by [12, pp. 108-130], and we have classified them into the following groups:

A) (group) discussions

B) drama activities and role plays

C) simulations

D) games

E) discovery activities (heuristic methods)

Discussions performed in small groups focus on exchanging ideas or experiences, solving moral dilemmas, or expressing opinions on global issues. Learners gain the experience of presenting their opinions, arguing, justifying their cases, but on the other hand they also learn how to listen to other people and learn to understand and tolerate their points of view. Even though the language goal of the discussion is practising speaking for fluency, it is essential that learners also achieve the extra-linguistic goal of the discussion and arrive at a compromise, solve a problem, make a suggestion or persuade the others. This is because the language is not taught for the sake of language, it is taught as a means of communication and needs to be used in language lessons like that. Discussions are demanding from the language point of view, as well as from the point of cognitive skills of learners and are, therefore, used with more advanced learners. Among the most common discussions are group discussions, pyramid discussions, or debates (which are more formal than discussions).

On the other hand, role-plays and various drama activities can be used at all levels and with all age groups. They may be controlled, e.g. in situational dialogues in which learners practise functions of the language, and find out what language, and how it is used in various social situations; or in grammar-oriented role-plays. At low levels of language proficiency, role plays and drama activities are rehearsed. At higher levels they may also be used to practise language for fluency, which means learners play the given roles without rehearsing them. The advantage is that role-plays and drama activities simulate various social situations thanks to which learners are not limited by the language which is commonly used in the classroom: they can be angry or excited; they can be on a trip or in a shop; they can play surgeons or journalists. In more creative activities they can be asked to dramatize a story, play the ending of a story or perform a dialogue between two characters.

Simulations differ from role-plays in that learners play themselves and behave in the same way they would if they were in the same situation outside the class. Among the most common simulations are interviews (learners interview each other to gain some personal information) and surveys (oral or written). Depending on the objectives, they can be placed anywhere on the continuum between controlled and free activities. For example, surveys known as Find someone who are highly controlled; on the other hand, learners can be asked to do a survey in which they use language freely. 
Another group of activities used in the language classroom are games which are motivating and activate learners. There are lots of various games used for language learning. Many of them are controlled, but some of them enable learners to produce language freely. [8, p. 97] divide games into interactive and non-interactive. Interactive games require the co-operation of learners. In these games learners communicate together and influence each other In games which are not interactive learners work individually and the results of their activity are not dependent on the others (quizzes, crossword puzzles). Even though games are very motivating and can be used in any stage of the lesson, some authors warn against using them too often because many of them concentrate on isolated words and are de-contextualized [18, p. 102]. Many authors also warn against using competitive games frequently because they may discourage slow-learners or low-achievers from participating in them.

As far as heuristic methods are concerned, discovery activities which help learners 'discover' grammatical rules are most commonly used. Learners do not discover rules completely by themselves; they are guided either by their teacher's questions or by questions in the textbook. The questions may concentrate on the form, function or use of a grammatical structure. In other discovery activities learners may also be asked to discover rules of pronunciation or spelling or to discover the meaning of new vocabulary through identification, selection, matching, classifying, etc. Among heuristic methods are also tasks in which learners are asked to predict the content of a text or the continuation of a story (in pre-listening or pre-reading activities or during the process of listening or reading), various kinds of projects and brainstorming.

The use of the above mentioned activities depends on the language level of learners. Especially those that require them to produce authentic output and to use language in unrehearsed situations creatively can only be used if learners' language proficiency is on, at least, $\mathrm{B} 1$ level of the CEF because in order to enjoy doing them learners must have already developed some secondary language skills. If used reasonably, however, they help learners to understand that the foreign language is a means of communication, not just one of the school subjects.

\subsection{Characteristic Features of Activities}

Learners' activity in the learning process has been justified by the constructivist theory of learning. Active participation in learning contributes to the development of learners' personalities, and their cognitive and affective skills. In the following part we will briefly mention some characteristic features of activities and discuss their influence on learners' personalities.

Above all, we will mention that learners' activity has a strong influence on the development of positive affective qualities, as well as on their motivation. The involvement and engagement with the learning process enabled by the use of activities (or activating methods) supports the development of learners' positive affective qualities. According to [7, p. 121] positive affective qualities are essential because they have the potential to influence the success in learning. Learners whose attitudes towards a subject, a teacher or the subject matter are positive are likely to be motivated and achieve good results.

Positive affective qualities play a great role in language learning as well. In addition to giving learners opportunities to work actively and be engaged in the learning process it is also important that the teacher creates such an atmosphere in the classroom in which learners are not afraid to talk in a foreign language even though they are aware of errors they make. The teacher should also respect their new "'language ego' intertwined with the second language" because it "can easily create within the learner a sense of fragility, a defensiveness, and a raising of inhibitions [2, pp. 61-64]." Positive affective qualities also influence the intrinsic motivation of learners which is considered to be one of three basic conditions of successful language learning [19, p.14].

Another characteristic feature of activating methods is the development of cognitive functions of learners (creativity, evaluation) because they are asked to solve various problems independently. In foreign language learning creativity is understood as the ability to comprehend and produce language in unrehearsed communicative situations, which requires receptive and productive creativity. In other words, learners are able to understand unknown texts (the analysis of the language learners are exposed to) and use the target language to express their own ideas (the creative production of the target language). In addition to that their creativity is also developed in various problem-solving tasks in which the problems are usually linked with the extra-linguistic reality. Through expressing their opinions, feelings and attitudes learners solve these problems using the target language as a means of communication. In discovery activities which help learners gain explicit language knowledge learners use their higher-order thinking skills to solve language problems dealing with the form, meaning and use of language structures.

Furthermore, activating methods (activities) contribute to the socialization of learners' behaviour. The abilities to co-operate, listen to and tolerate the opinions of others are necessary pre-conditions of team work. Many authors stress the importance of such co-operation because it increases learners' ability to adapt to various conditions and be responsible for each other and their learning. In co-operation with their peers they also learn to understand values, respect each other and become more self-confident.

Another aspect that we would like to pay attention to is classroom communication because it influences the learning process, learning styles, as well as the activity of students. In a traditional classroom knowledge is transmitted to learners, they receive it passively and the time for practising their skills as well as student talking time is reduced. On the other hand, activities open space for active participation of learners and for multi-dimensional communication (communication between learners, not only between the teacher and a learner). Kinds of questions are another important aspect of classroom communication. Referential questions and production questions open space for genuine communication and for productive use of language. 


\section{Conclusion}

In conclusion, doing activities in language classroom is a great contribution for learners because they help them develop self-confidence, creativity and spontaneity without being afraid of failure [9]. They also make it possible for learners to take an active part in the learning process, develop creative competences, learn to co- operate in groups, become aware of their own attitudes and values, take part in decision-making and evaluate. Their application in foreign language lessons helps learners understand explicit language knowledge much better and, which is much more important, it helps them gain implicit knowledge, language habits and finally secondary language skills and thus acquire the communicative competence which is the ultimate objective in language learning.

\section{References}

[1] BALINT, L.: Some Principles of the Reform of Our School System (in Slovak), Pedagogicke spektrum, 1, pp. 54-68, ISSN 13355589,2007

[2] BROWN, H. D.: Teaching by Principles. An Interactive Approach to Language Pedagogy, London, Longman. ISBN 0-13-028283-9, 2001

[3] CHODERA, R., RIES, L.: Teaching Foreign Languages at the Threshold of the New Century - part I (in Czech), Ostrava, Ostravska univerzita, 1999 ISBN 80-7042-157-6, 1999

[4] CHODERA, R.: Teaching Foreign Languages: Introduction to Methodology (in Czech), Praha, Academia, ISBN 80-200-1213-3, 2006

[5] Common European Framework, [cit. 2008-10-25], Internet: http://www.coe.int/t/dg4/linguistic/Source/Framework_EN.pdf, 2007

[6] FULKOVA, E.: Chapters from General Didactics (in Slovak), Bratislava, Infopress, ISBN 80-85402-78-5, 2006

[7] GAVORA, P.: What Are My Pupils Like: Pedagogic Diagnosis of Pupils (in Slovak), Bratislava, Vydavatelstvo Praca, ISBN 80-7094335-1, 1999

[8] KOTRBA, T., LACINA, L.: Practical Use of Activating Methods in Education (in Czech), Brno, Spolecnost pro odbornou literaturu, ISBN 978-80-87029-12-1.

[9] KRALOVA, Z., KRAJCOVIC, M.: Variance in a Second Language Pronunciation Quality, Communications - Scientific letters University Zilina, 4/2009, pp. 15-23

[10] LARSEN-FREEMAN, D.: Techniques and Principles in Language Teaching, New York, Oxford University Press, ISBN 0-194355748, 2000

[11] LOJOVA, G.: Theory and Practice of Teaching Foreign Language Grammar (in Slovak). Bratislava, Monitor Promotion, ISBN 80968040-22, 2004

[12] MANAK, J., SVEC, V.: Teaching Methods (in Czech), Brno, Paido, ISBN 80-7315-039-5, 2003

[13] PRATOR, C.: Development of a Manipulation - Communication Scale, Education Resources Information Centre, [cit. 2009-02-23], http://www.eric.ed.gov/ /ERICWebPortal/custom/portlets/recordDetails/detailmini.jsp?_nfpb=true\&_\&ERICExtSearch_Search Value_0=ED041258\&ERICExtSearch_SearchType_0=no\&accno=ED041258, 1969

[14] RAFAJLOVICOVA, R.: Testing Verb Forms through Secrete-point and Open-ended Tasks, Presovska univerzita, Presov, FHaV, ISBN 80-8068-002-7, 2000

[15] REPKA, R.: From Language Functions to Communicative Teaching (in Slovak), Bratislava, SAP, ISBN 80-85665-89-1, 1997

[16] REPKA, R.: A Course in English Language Didactics, Bratislava, LINGOS, ISBN 80-89113-20-6, 2005

[17] SCRIVENER, J.: Learning Teaching, Oxford, Macmillan Education, ISBN 1-4050-1399-0, 2005

[18] THORNBURY, S.: How to Teach Vocabulary, Oxford University Press, Oxford, ISBN 0582 429668, 2004

[19] WILLIS, J.: A Framework for Task-Based Learning, London, Longman, ISBN 0-582-25937-8, 1996

[20] The Law on Education No. 245/2008 Z. z. (in Slovak), Bratislava, Ministerstvo skolstva SR, [cit. 2008-11-08], http://www.minedu.sk/data/USERDATA/Legislativa/ Zakony/245_2008.pdf, 2008. 